not exist? After all, many diagnostic entities are based on aetiology, not symptoms.

Tairawhiti Area Health Board

JAMES Eva

Private Bag

Gisborne, New Zealand

\section{'Black' issues in mental health practice in the United Kingdom}

DeAR SIRS

In the year beginning October 1990, I admitted 10 African-Caribbean patients at the Royal London Hospital (St Clement's), three informally, two under Section 2, one under a Section 4, later converted to a Section 2, and four by way of the penal system (one Section 35, two under Section 37 and one Section $37 / 41$ ). Seven of these patients were violent before admission, of whom six were violent towards nursing staff. With the exception of one female patient, each had been taking illegal drugs such as cannabis and LSD. The diagnoses made were: affective personality disorder (1), drug-induced psychosis (2) and schizophrenia and drug abuse (7).

Only a handful of these 10 patients were referred as non-emergency cases by their general practitioners, seven were admitted under Sections of the Mental Health Act 1983, four had come in by way of the Prison Service, six had been violent before and during their admission, and nine had been on illicit drugs. Follow-up showed many continuing to take drugs and being readmitted in a floridly psychotic state with others simply not showing up for appointments. This handful of patients fulfils all of the 'racial sterotypes' about which African-Caribbean people bitterly complain and whose treatment provokes considerable controversy. For many AfricanCaribbeans, what is done for their mentally ill is from a racist perspective which has a negative effect on the utilisation of psychiatric services.

The College (1989) has been very concerned about racism in the training and employment of psychiatrists, and in the delivery of care to mentally disturbed members of ethnic minorities. The Special Committee set up in 1987 proposed 26 Recommendations aimed at reducing the impact of racial thinking on psychiatric training and practice.

I think that now is the time to try to find out whether the complaints of African-Caribbeans are justified, that they make use of the avaiable resources, and that they are properly treated. Psychiatrists of AfricanCaribbean origin should play a positive and constructive part in this process.

I would recommend that the Executive Committees of the African-Caribbean Medical Society, the AfroCaribbean Mental Health Association and the National Black Mental Health Association should arrange to meet with the members of the College
Special Committee and use the 26 Recommendations as a basis for discussion.

The Royal London Hospital (St Clement's)

I. O. AZUONYE London E3 4LL

\section{Reference}

Royal College of Psychiatrists (1990) Statement by Council on psychiatric practice and training in British multi-ethnic society. Psychiatric Bulletin, 14, 432-437.

\section{DeAR SirS}

Dr Azuonye describes 10 patients under his care, including the nature of their referral, their legal status and their mental state. There is nothing in his description to indicate poor medical practice, nor discrimination against these patients and the only distinguishing feature of a racial nature is that he categorises these patients as African-Caribbean.

We would certainly welcome a well-researched investigation into the nature of the treatment received by racial minorities. The Special (Ethnic Issues) Committee has now reported to the College and therefore been discharged. However, if the organisations Dr Azuonye mentioned would like to make contact with the College concerning AfricanCaribbean mental health issues, I would be very happy to meet them.

$$
\text { Professor A. C. P. Sims }
$$
President

\section{Terminator 2 - Judgement Day}

\section{DEAR Sirs}

I agree with Ralph Footring (Psychiatric Bulletin, December 1991, 15, 796-797), that 'Terminator 2' was a thoroughly enjoyable movie but that psychiatric care was displayed in its worst possible light.

An altogether different psychiatric perspective in the film is in the character of the Terminator himself. $\mathrm{He}$ is a robot without emotions who has been constructed with the ability to learn from experience. During the film he is curious about the tears of the boy he has been programmed to protect: he cannot comprehend them. Later on the boy urges him not to kill anybody: he does not understand this either. This theme of understanding another's existence and feelings is pursued in the film within the relationship between the Terminator and his ward. The film ends with the robot seemingly having grasped some notion of what human emotions are, and implicitly even having some of his own. The screenplay makes this an important part of the film.

Autistic children and adults have difficulty in acknowledging the existence of others and being emotionally connected to the world. There is considerable public fascination over autistic states of mind. This is reflected in popular media. Mr Spock in 